\title{
Harmadikablak-szindróma - osztályozás, diagnózis, terápia
}

\author{
Kalinics Péter dr. ${ }^{1,2}$ - Gerlinger Imre dr. ${ }^{1}$ - Révész Péter dr. ${ }^{1}$ \\ Bakó Péter dr. ${ }^{1}$ - Végh Ildikó dr. ${ }^{1}$ - Kovács Márton dr. ${ }^{1}$ - Fehér Attila dr. ${ }^{3}$ \\ ${ }^{1}$ Pécsi Tudományegyetem, Általános Orvostudományi Kar, Fül-, Orr-, Gégészeti és Fej-Nyaksebészeti Klinika, Pécs \\ ${ }^{2}$ Tolna Megyei Balassa János Kórház, Fül-Orr-Gégészeti Osztály, Szekszárd \\ ${ }^{3}$ Kanizsai Dorottya Kórház, Fül-Orr-Gégészeti Osztály, Nagykanizsa
}

\begin{abstract}
Halláspanasszal számos beteg fordul orvoshoz. A rutinszerúen elvégzett súgottbeszéd-, hangvilla- és tisztahangküszöb-audiometriai vizsgálat alapján vezetéses, sensorineuralis, illetve a kettő együttes fennállása esetén kevert típusú halláscsökkenést különböztetünk meg. Vezetéses halláscsökkenés létrejöhet mind a külső, mind a közép- vagy a belső fül veleszületett vagy szerzett rendellenességei esetén. Amennyiben a stapediusreflex kiváltható, ugyanakkor a betegnél nincs jelen a külső fület, valamint a középfület érintő kórfolyamat, felmerül a harmadikablak-szindróma lehetősége. A kórkép okaként egy, a belső fül csontos tokján „harmadik ablakként” funkcionáló laesio van jelen, amely az ovális ablakon keresztül beérkező hangenergia egy részét elvezeti, mielőtt az a kerek ablakon át kivezetődik a középfülbe. A diagnózis felállítása gyakran nehéz feladat elé állítja a klinikust, melyhez a megfelelő audiológiai, illetve képalkotó vizsgálatok elvégzése elengedhetetlen. Tekintettel arra, hogy a panaszok megszüntetésére számos műtéti módszer került leírásra, közleményünkben átfogó képet adunk a kórkép etiológiájáról, diagnosztikájáról, terápiájáról, valamint bemutatjuk saját kezdeti tapasztalatainkat is 2 eset prezentálásával.
\end{abstract}

Orv Hetil. 2020; 161(46): 1944-1952.

Kulcsszavak: belső fül, dehiscentia, harmadik ablak, vezetéses halláscsökkenés

\section{Third window syndrome - classification, diagnosis, therapy}

Patients frequently present to the physician with hearing loss. Routine hearing tests include speech field (whisper test), tuning forks and pure tone threshold audiometry, which can identify the presence of sensorineural hearing loss, conductive hearing loss or a combination of both (mixed type). Conductive hearing loss can be a symptom of many different conditions. These include congenital or acquired malformations of the outer, middle and inner ear. If a conductive hearing loss with intact stapedial reflexes are recorded and in the absence of outer or middle ear pathology, then the third window syndrome should be considered. The cause is a bony defect on the otic capsule that acts as a 'third window', dissipating the incoming sound energy. Without the appropriate audiological and imaging tests, the diagnosis of the condition is challenging in clinical setting. Several surgical techniques have been described to treat the condition. The authors give a comprehensive review of the etiology, diagnosis and treatment of the disease presenting their initial experiences with 2 cases.

Keywords: conductive hearing loss, dehiscence, inner ear, third window

Kalinics P, Gerlinger I, Révész P, Bakó P, Végh I, Kovács M, Fehér A. [Third window syndrome - classification, diagnosis, therapy]. Orv Hetil. 2020; 161(46): 1944-1952.

(Beérkezett: 2020. április 11.; elfogadva: 2020. május 17.)

\section{Rövidítések}

HRCT $=$ (high-resolution computed tomography) nagy felbontású számítógépes tomográfia; STR = stapediusreflex; VEMP $=($ vestibular evoked myogenic potential $)$ vestibularisan kiváltott miogén izomválasz
Az ép dobhártya mellett előforduló vezetéses halláscsökkenés hátterében a leggyakrabban a középfül egyes struktúráinak, különösen a hallócsontoknak a kóros elváltozásai állnak. Ilyen esetekben a végső diagnosztikai eljárás a dobüreg feltárása, az ún. exploratív tympanoto- 
mia, mely egyben terápiás lehetőséget is kínál. Időnként azonban a mütét során hiányoznak a halláscsökkenést megmagyarázó patológiai elváltozások a középfülben [1-3]. Az ilyen esetek hátterében a belső fül valamelyik struktúrájának olyan eltérése állhat, mely harmadik ablakként funkcionálva kivezeti a hangenergia egy részét a belső fülből [4-7].

\section{Anatómiai háttér}

Az oticus capsulán a belső fül csontos tokját értjük, amely a belső fül folyadéktereit csaknem teljesen körülveszi, azonban bizonyos összeköttetések révén a belső fül direkt kapcsolatban van a középfüllel, illetve az intracraniummal. A középfülből a nyomás az első, illetve a második ablakon keresztül, az ún. ovális és a kerek ablakon át éri el a belső fület, míg a középső agyscalával az aquaeductus cochleae, a hátsó scalával pedig az aquaeductus vestibuli teremt kapcsolatot: az előbbi a scala tympani, az utóbbi a vestibulum révén ( $1 / A$ ábra). A felsoroltakon kívül léteznek még további fiziológiás ablakok is a belső fül folyadékterei és az intracranium között, amelyek ereket és idegeket tartalmaznak, ezek azonban szúk csatornaként jellemezhetők. Normális esetben a kerek ablak és az ovális ablak területének nagysága megegyezik, a korábban felsorolt többi ablakon keresztül pedig nem távozik jelentős hangenergia a belső fülből [8-10]. A harmadik ablak esetén a fiziológiás összeköttetéseken felül jelen van még egy defektus a csontos borításon, mely a hangenergia elszökéséhez, így halláscsökkenéshez vezet [11]. Ugyanígy elófordul energiaveszteség abban az esetben, ha az összeköttetések a normálisnál tágabbak [12].

\section{Diagnózis}

A harmadikablak-szindróma kizárása a vezetéses halláscsökkenés differenciáldiagnosztikájának lényeges eleme, különösen intakt dobhártya és légtartó dobüreg esetén.
A szindróma utánozhatja az otosclerosis, illetve más, stapesfixációval járó betegségek tünettanát. Számos vizsgálat alkalmazható a diagnózis felállításához. Tisztahangküszöb-audiometria során típusosan az alacsony frekvencián jelen levő vezetéses halláscsökkenés képét látjuk, esetlegesen szupranormális, azaz épnek tekintett hallásküszöbnél is alacsonyabb csontküszöbbel (negatív dB-értékű), ami különösen a félkörös ívjáratok dehiscentiájára jellemző $[7,13,14]$. A középfület érintő kórképekkel szemben az akusztikus reflexek (stapediusreflex, STR), az otoakusztikus emisszió és a VEMP (vestibularisan előidézett miogén izomválasz) is kiváltható $[5-7,13]$. Az STR a belső fület védi az erős hangokkal szemben a stapestalp ovális ablakból történő „kibillentése” révén. Az otoakusztikus emisszió a cochleában elhelyezkedő külső szőrsejtek motoros tevékenységének következtében keletkező, igen kis intenzitású hangjelenség, amely retrográd irányban az ép hallócsontláncolaton és a dobhártyán keresztül a külső hallójáratba jut, ahol regisztrálható. A VEMP vizsgálja az erős akusztikus ingerlés (körülbelül 100 dB) hatására bekövetkező izomkontrakciókat, amelyek szerepe a törzs, illetve a fej helyzetének stabilizálása. Vezetéses halláscsökkenés esetén, amennyiben a hallócsontláncolaton keresztül nem jut be a hang a belső fülbe, a VEMP nem váltható ki. A hallásküszöbnél körülbelül 80-90 dB-lel hangosabb hang váltja ki a VEMP-et, vizsgálata a hallócsontláncolat mobilitásáról ad információt. Harmadikablak-szindróma esetén a halláscsökkenés mellett a betegeknél vestibularis tünetek is előfordulhatnak, amennyiben a nyomásváltozások az egyensúly-érzékelésben szerepet játszó struktúrákra is áttevődnek. Ezek közül kiemelendő a Tullio-jelenség, amely a nagy intenzitású hang hatására kiváltott szédülést jelenti, valamint a Hennebert-tünet, melyen a külső hallójáratra kifejtett nyomás révén provokált szédülést értjük [11]. Vertigót okozhat a Valsalva-manőver is. A képalkotó vizsgálatok közül a sziklacsont-HRCT szerepe diagnosztikus, segítségével a csontos defektusok azonosíthatók.

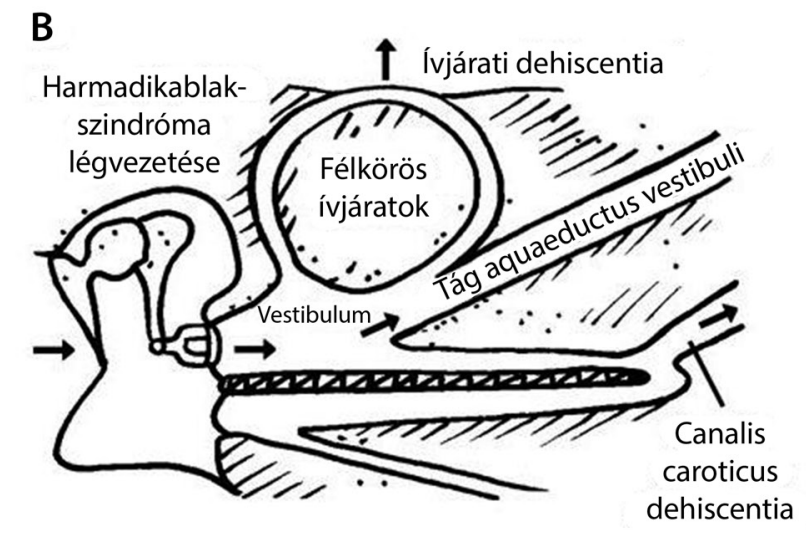

\section{B}

A

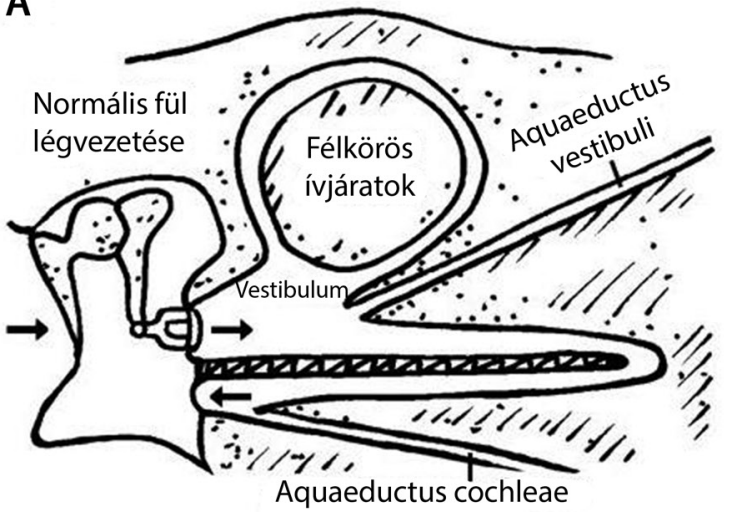

1. ábra

A hanghullám haladási iránya légvezetés esetén. A) A hanghullám haladási iránya normális belső fülben légvezetés esetén. A rezgés a középfülön át a stapes talpáról az ovális ablakon át a csigába jut, majd végighaladva azon a kerek ablak membránján csillapodik le (nyíllal jelölve). Harmadikablakszindróma esetén (B) a csigába jutott hanghullám a kerek ablak előtt lecsillapodik a harmadik ablakként funkcionáló laesión keresztül. A magas hangok elektromos jellé történő alakítása a csiga alapján, az ovális ablakhoz közel, a mély hangok átalakítása a csiga csúcsán történik, ezért jellemzően harmadikablak-szindróma esetén az alacsony hangoknak megfelelően jelentkezik halláscsökkenés (grafika: Kánya Péter) 


\section{Osztályozás}

A harmadikablak-szindróma hátterében állhat a belső fül valamelyik meghatározott struktúrájának defektusa, illetve leírták, hogy a temporalis csont egészét érintő Pagetkór esetén látott vezetéses halláscsökkenés megjelenése úgynevezett diffúz harmadikablak-szindrómának tudható be [15].

A belső fül csontos tokjának defektusai elhelyezkedhetnek a félkörös ívjáratok, a csontos vestibulum, illetve a cochlea területén ( $I / B$ ábra), az alábbiakban ezeket részletesen ismertetjük.

- Felső ívjárati dehiscentia (2. ábra): a felső ívjárat csontborítékának hiánya, melynek következtében az ívjá-

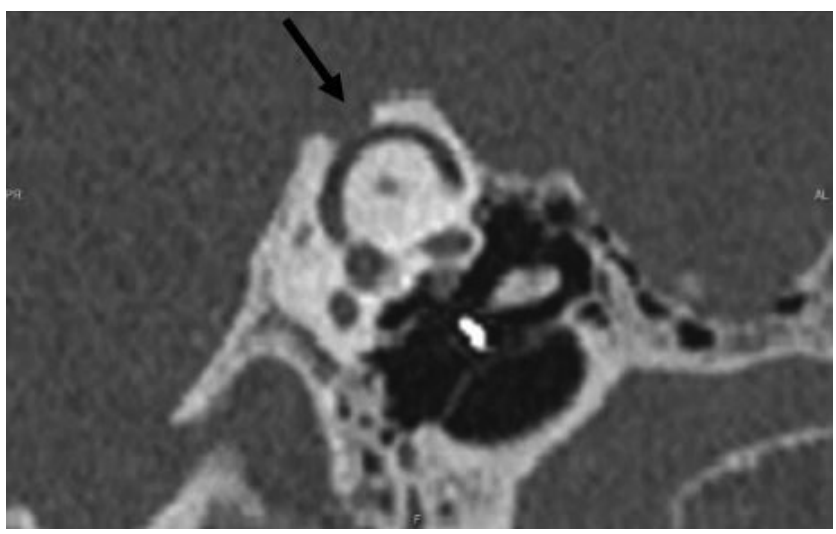

Koronális síkú sziklacsont-HRCT-felvétel. Nýlllal jelölve a ba oldali felső ívjárati dehiscentia (saját anyag)

HRCT = nagy felbontású számítógépes tomográfia

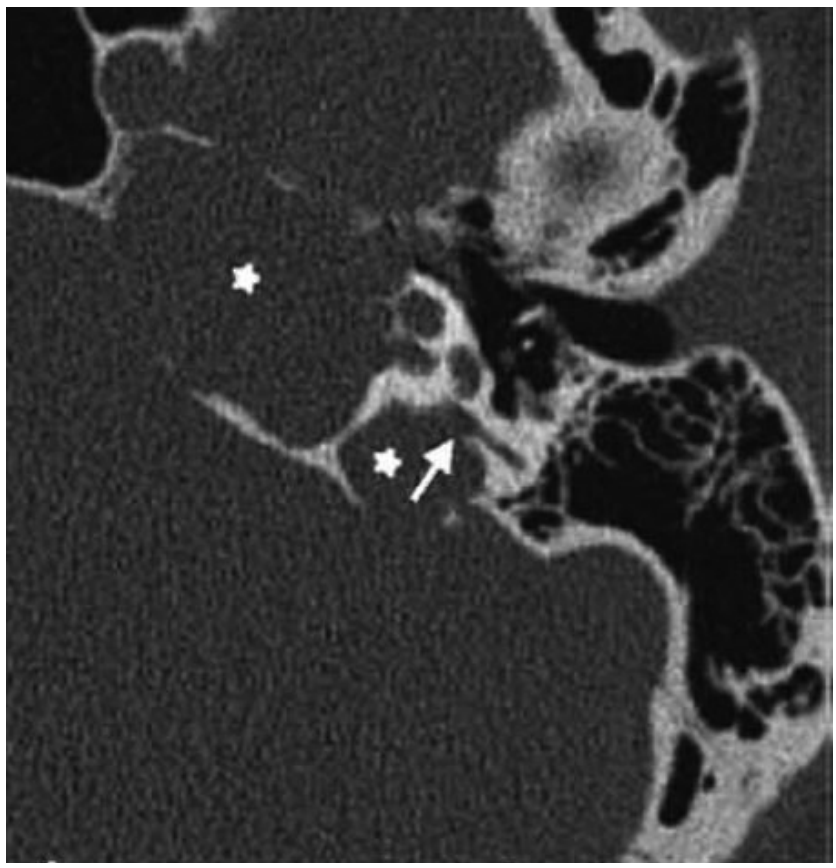

3. ábra

Axiális síkú sziklacsont-HRCT-felvétel. Bal oldali sziklacsontcsúcsi cholesteatoma (csillaggal jelölve) következtében kialakult hátsó ívjárati dehiscentia, nyíllal jelölve [15]

HRCT = nagy felbontású számítógépes tomográfia rat és a középső scala durája között direkt nyomásváltozások jöhetnek létre. Tünetei a vezetéses halláscsökkenés vagy szédülés, illetve ezek együttes fennállása [5-7, 13]. A halláscsökkenés típusosan az alacsony frekvenciákat érinti (2000 Hz-ig), a csontküszöb lehet szupranormális, azaz $0 \mathrm{~dB}$-nél is jobb. Az STR és a VEMP kiváltható $[5-7,13]$.

- Hátsó ívjárati dehiscentia (3. ábra): hátsó ívjárati dehiscentia esetén az intracraniummal, illetve a bulbus venae jugularissal kommunikálhat az ívjárat [14, 16, 17].

- Lateralis ívjárati dehiscentia (4. ábra): a leggyakrabban a középfülben zajló patológiás folyamat szövődménye. Ez lehet cholesteatoma, illetve krónikus gennyes mesotympanalis középfülgyulladás miatt létrejött granu-

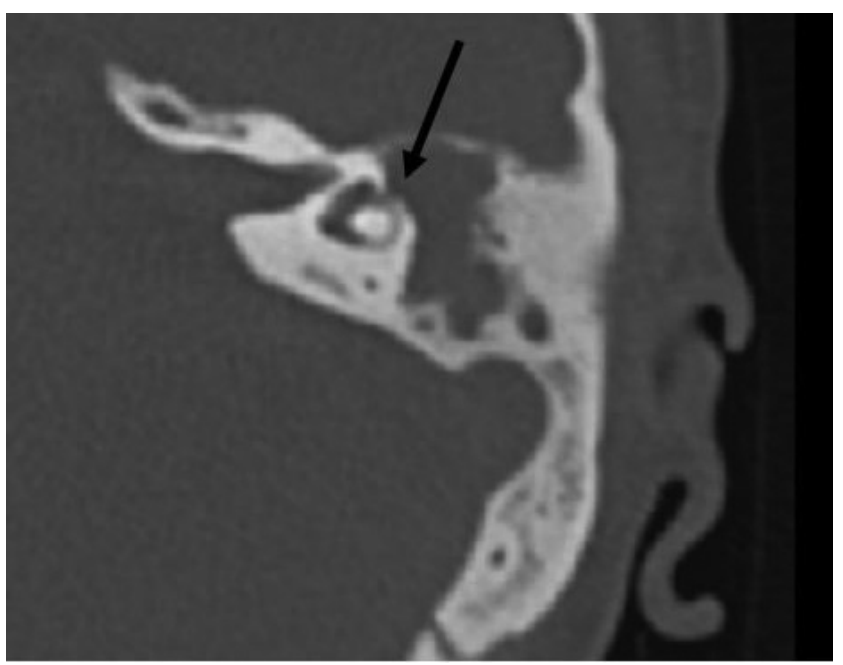

4. ábra

Axiális síkú koponya-CT-felvétel. A bal oldali lateralis ívjárati dehiscentia nyíllal jelölve

CT = számítógépes tomográfia

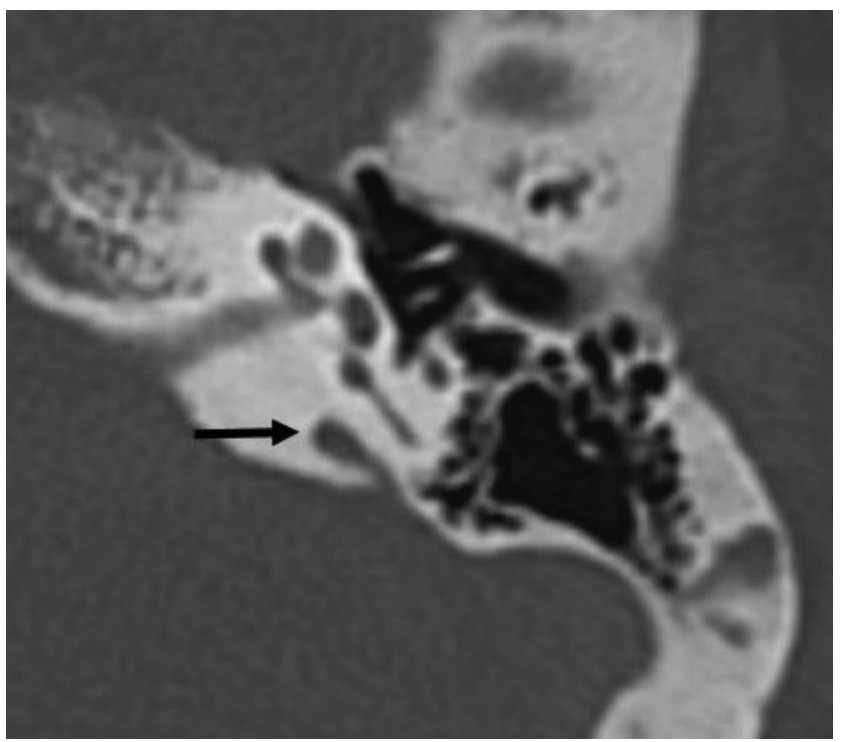

5. ábra Axiális síkú sziklacsont-HRCT-felvétel. Jobb oldalon a tág aquaeductus vestibuli nyíllal jelölve

HRCT = nagy felbontású számítógépes tomográfia 


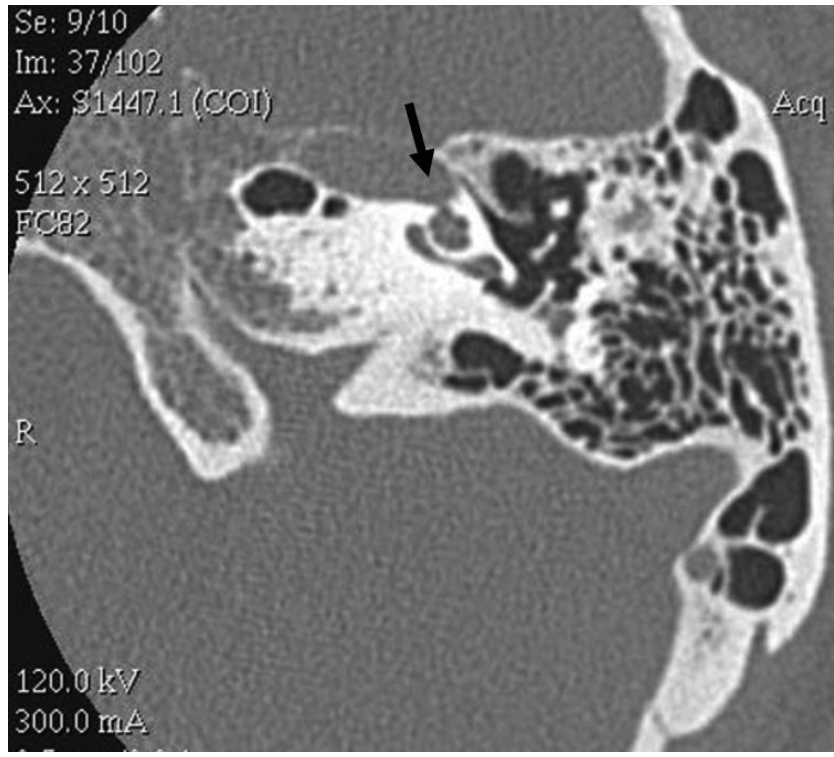

6. ábra

Axiális síkú sziklacsont-HRCT-felvétel. A cochlea és a canalis caroticus közötti dehiscentiát nyíl jelöli [24]

HRCT = nagy felbontású számítógépes tomográfia

lációs szövet által okozott erozív osteitisnek, valamint otosclerosis miatt mútét kapcsán végzett fenesztrációnak a következménye [16, 18].

- Tág aquaeductus vestibuli (5. ábra): a leggyakoribb belsőfül-fejlődési rendellenesség; jellemzően korai sensorineuralis halláscsökkenéssel jár, és általában kétoldali megjelenésű. Több szerző leírta a mély frekvenciákon jelentkező csont-lég-rést [12]. Ezekben az esetekben a csontos vestibulum és az intracranium közötti kommunikáció révén alakulhat ki a vezetéses komponens.

- DFN-3 (X-kromoszómához kötött siketség „gusher" stapesszel): a kórkép kevert típusú halláscsökkenéssel és az elvégzett stapedotomia kapcsán, a stapestalp fenesztrációja során jelentkező jelentős perilymphacsorgással jár [19-23]. Alacsonyabb frekvenciákon nagyobb a csont-lég-rés, az STR pedig kiváltható lehet [19, 23]. Képalkotó vizsgálattal a belső hallójárat tágulata, gyakran csonthiány látható a belső hallójárat és a cochlea között $[22,23]$. Más szerzők leírták a belsó hallójárat és a vestibulum közötti kommunikációt, illetve az emellett megjelenő tág aquaeductus vestibulit [21, 24]. A stapestalp bizonyos esetekben fixált lehet [19, 23]. Mobilis stapestalp esetén az etiológia egy harmadik ablak jelenléte lehet a belső hallójárat és a belső fül valamelyik térsége (a scala vestibuli vagy a vestibulum) között. A feltételezett szupranormális csontküszöböt maszkolhatja a betegségre jellemző sensorineuralis halláscsökkenés.

- A cochlea és a canalis caroticus közötti dehiscentia (6. ábra): Kim és Wilson egy esetben számolt be róla sikertelen stapedectomiát követően [25].

\section{Terápia}

Az alábbiakban a felső ívjárati dehiscentia megoldására kifejlesztett módszereket tekintjük át. Az ívjáraton keresztül történő nyomás elszökésének megszüntetésére több módszert is kidolgoztak. Alkalmazható az ívjárat fedése (capping), annak occlusiója (plugging), valamint az ívjárat folytonosságának helyreállítása (resurfacing). Ezen eljárásokhoz csontpor, csontviasz, hidroxiapatit cement és lágy rész is felhasználható; az egyes technikákhoz alkalmazható anyagokra vonatkozóan nincs egységes irodalmi állásfoglalás, ezek egymással kombinálhatók [26-29]. Általánosságban elmondható, hogy az ívjárat fedése (capping) a tegmen tympani és a dura mater közé, folytonosságának helyreállítása (resurfacing) a tegmen tympani és az ívjárat közé helyezett grafttal történik [26], a publikált mútéti leírások azonban nem mutatnak teljesen egységes képet $[30,31]$. Több vizsgálat is leírta, hogy az ívjárat occlusiója, valamint folytonosságának helyreállítása jobb hosszú távú eredményeket mutatott, mint a folytonosság-helyreállítás önmagában, mert ebben az esetben az ívjárat nyomásváltozásra érzékeny maradhat, a teljes záródás nem garantált $[31,32]$. Goddard és Wilkinson 24 esetben számolt be a hallás javulásáról és a tünetek mérséklődéséről az occlusiós technika alkalmazásával [33]. Egy 64 beavatkozást számláló metaanalízis alapján a fedés és az occlusiós technika szignifikánsan sikeresebb eljárás a folytonosság-helyreállításhoz képest [26].

Elhelyezkedésénél fogva a felső ívjárat nehezen férhető hozzá, explorációja a középső agyscalán keresztül vagy a középfül üregrendszerén át, transmastoid feltárással érhető el. A középsőscala-feltárás segítségével direkt rálátás nyerhető az ívjáraton elhelyezkedő defektusra, de ehhez szükséges a temporalis lebeny eltartása, ami szövődményekhez vezethet. A módszert először Minor alkalmazta, aki az ívjárat occlusióját végezte el fascia, csontpor és fibrinragasztó keverékével, amelyre corticalis csontlemezt helyezett [11]. A transmastoid feltárás segítségével kiküszöbölhetők a középsőscala-feltárás hátrányai, a defektusra történő rálátás azonban korlátozottabb [31]. Kidolgozásra került a kerek ablak obliteratiója (round window reinforcement) is. Ezen mútéti technikákat részletesen ismertetjük a továbbiakban.

\section{Középsóscala-feltárás}

A felső ívjárati dehiscentia megoldását középsőscala-feltárásból először Minor és mtsai írták le [27]. A mütét lényege az eminentia arcuata felkeresése, amely a középsô scalán végzett $4 \times 4 \mathrm{~cm}$-es craniotomiát követően a temporalis lebeny felemelésével azonosítható a középső scala csontos alapján. Az eminentia arcuata magában foglalja az elülső ívjáratot, és a dehiscentia gyakran azonnal szembetűnő. Az ívjárat feltárását követően a defektus lefedhető (capping), vagy az ívjárat lezárható (plugging). 
A feltárás előnye, hogy direkt rálátást biztosít a defektusra, elkerülhető a csontos labyrinthus bizonyos részeinek elfúrása, illetve a koponyabázis szélesebb feltárása. A módszer legnagyobb hátránya, hogy a temporalis lebeny eltartása szövődményekhez vezethet.

\section{Endoszkóppal asszisztált középsöscala-feltárás}

A középső scalán végzett craniotomiát $(3 \times 2 \mathrm{~cm})$ követően, mikroszkópos vizualizáció segítségével a dura matert felemeljük, amíg az eminentia arcuata láthatóvá nem válik. Ezt követően $3 \mathrm{~mm}$ széles, 14 cm hosszú, 30 fokos merev endoszkóp segítségével azonosítjuk a defektust. A manipuláció során a temporalis lebeny House-Urbanretraktor segítségével tartható el. A durát leválasztjuk a defektus medialis aspektusáról, majd csontviasz felhasználásával zárjuk a defektust az ampulláris és az ellenkező irányban egyaránt [34]. Peng és mtsai hidroxiapatit csontcement segítségével végezték az ívjáratok folytonossághiányának helyreállítását (resurfacing), közleményükben 10 esetben számoltak be jó eredményrôl [35].

\section{Transmastoid feltárás}

Mastoidectomiát követően szkeletizáljuk a sinus sigmoideust, a középső és a hátsó scala durát, valamint a félkörös ívjáratokat. A dehiscentia azonosítását követően felemeljük a középső scala duráját a felső ívjáratról. Az ívjárat folytonossága helyreállítható (resurfacing), vagy két ponton fenesztráljuk az ívjáratot $1 \mathrm{~mm}$-es gyémántfúróval, melyeken keresztül az ívjárat obliterálható (plugging) [30]. Ez az eljárás a craniotomia elkerülése révén alacsonyabb morbiditást és rövidebb kórházi ápolási időt eredményezhet. Hátránya, hogy a dehiscentiára nehe-

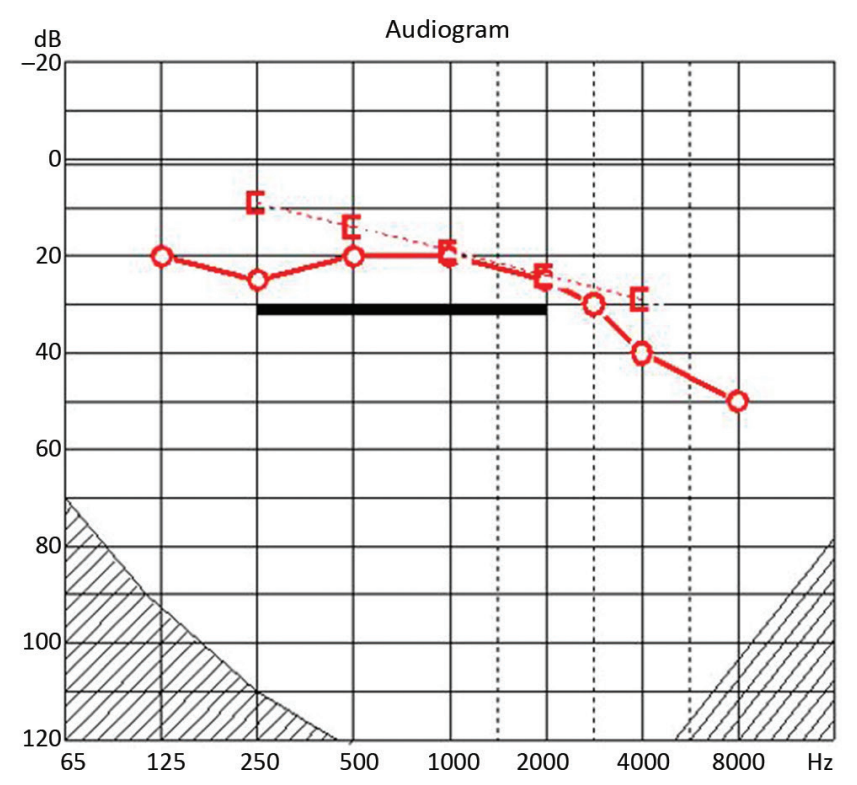

zebb a rálátás, illetve alacsonyan fekvő tegmen esetén a dura mater sérülésének veszélye lényegesen nagyobb a felső ívjárattól lateralisan [33].

\section{Kerekablak-obliteratio (reinforcement)}

A külső hallójárat felőli behatoláskor a tympanomeatalis lebeny felemelését követően tympanotomia során azonosítjuk a kerek ablak fészkét, szükség esetén canaloplasticát is végzünk a jobb rálátás érdekében. A kerek ablak fészkét és a promontoriumot denudáljuk, majd a kerek ablakot megerősítjük fasciával, tragusporccal, porchártyával vagy zsírral [36]. Ezt követően a lebenyt visszahelyezzük, és a külső hallójáratot kitamponáljuk. Az eljárás enyhe panaszokkal rendelkező betegeknek javasolható, és alacsony rizikójú a középsőscala-, illetve a transmastoid feltáráshoz képest. A kerek ablak teljes lezárása is elvégezhető, egyes szerzők azonban a posztoperatív időszakot követően a tünetek súlyosbodását írták le [36].

\section{Esetismertetés}

\section{Elsö eset}

Egy 61 éves nőbetegnél korábban más intézetben vezetéses halláscsökkenést diagnosztizáltak. Az elvégzett mikroszkópos fülvizsgálat során ép dobhártyát és légtartó dobüreget találtak. STR-, illetve VEMP-vizsgálat nem történt. Exploratív tympanotomiát végeztek otosclerosis gyanújával. Az operáció során stapedectomiát végeztek, a mútétet követően azonban az audiogramon látott csont-lég-rés nem záródott, a beteg hallása nem javult. Reoperáció mérlegelése céljából küldték Klinikánkra. Az elvégzett tisztahangküszöb-audiometriai vizsgálaton

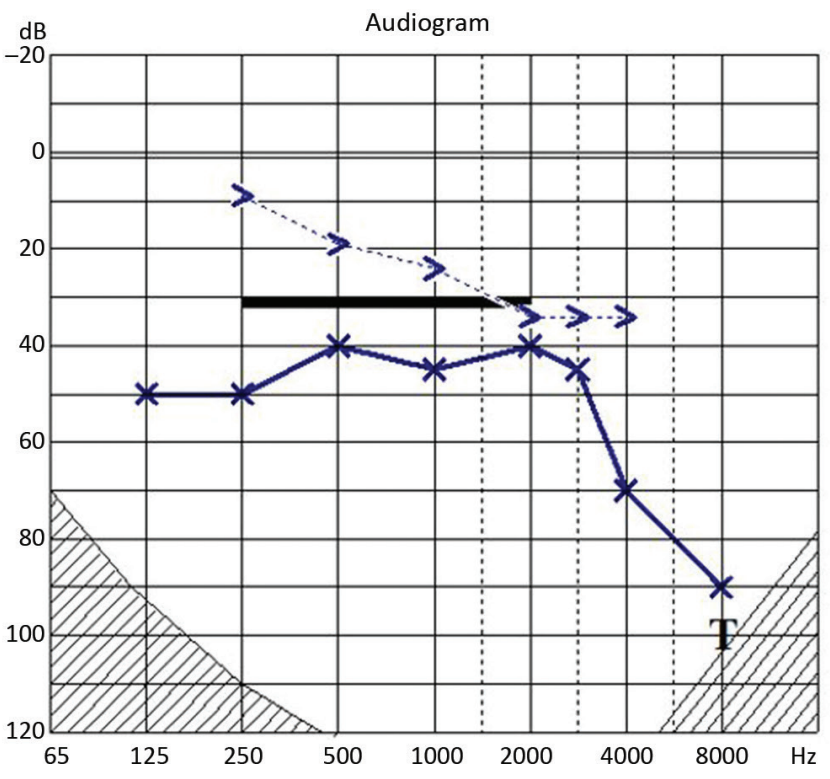

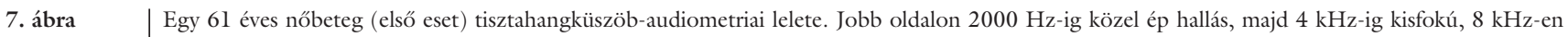
közepes fokú sensorineuralis halláscsökkenés látható. Bal oldalon $3000 \mathrm{~Hz}$-ig közepes fokú, magas frekvenciákon nagy-, végül súlyos fokúvá váló, kevert típusú halláscsökkenés; tinnitus $8000 \mathrm{~Hz}$-en mérhető 


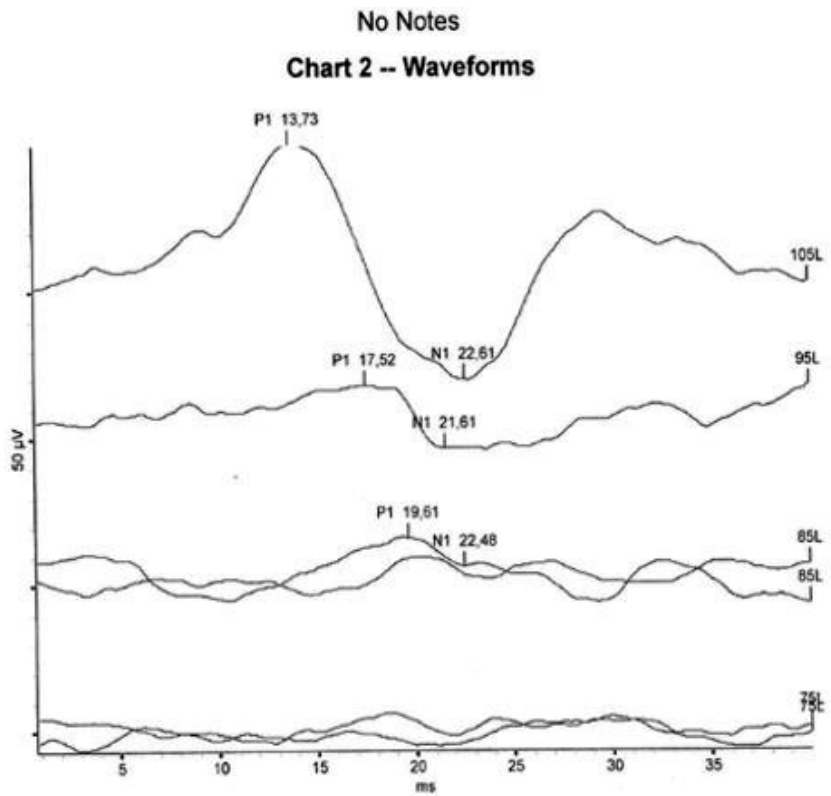

8. ábra

Egy 61 éves nőbeteg VEMP-lelete. Látható a típusos $\mathrm{P}_{1} \mathrm{~N}_{1}$-válasz, mely még $85 \mathrm{~dB}$-es intenzitású hang hatására is regisztrálható volt

VEMP $=$ vestibularisan kiváltott miogén izomválasz

döntően vezetéses típusú, bal oldali halláscsökkenés ábrázolódott közel ép jobb oldali hallás mellett (7. ábra). A VEMP (8. ábra) és az STR kiváltható volt az érintett fülön. A leletek alapján a más intézetben gyanított otosclerosis helyett felmerült a harmadikablak-szindróma lehetősége. Képalkotó vizsgálatot kértünk, s az elvégzett sziklacsont-HRCT felvételein bal oldali felső ívjárati dehiscentia igazolódott (2. ábra). Mütéti megoldást javasoltunk, ezt azonban a beteg eddig visszautasította.
REFLEX THRESHOLD

TEST 12

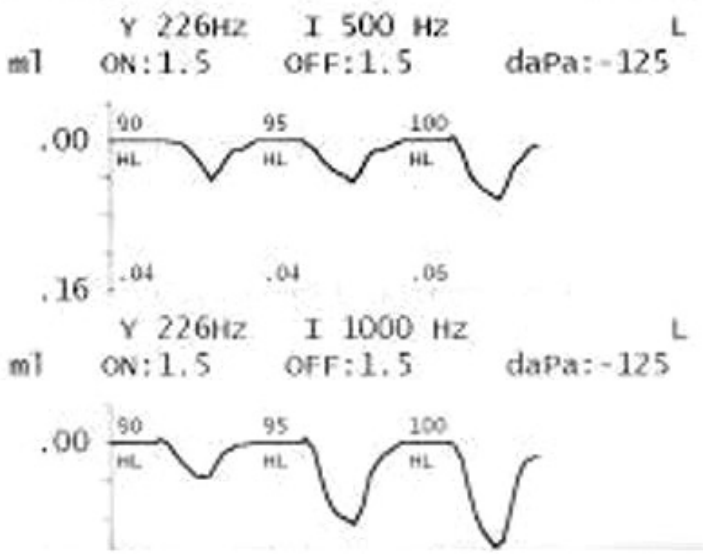

10. ábra

Egy 76 éves nóbeteg stapediusreflex-lelete. Bal oldalon ipsilateralisan adott $500 \mathrm{~Hz}$-es és $1000 \mathrm{~Hz}$-es hanggal $90 \mathrm{~dB}$-en is kiváltható a stapediusreflex

\section{Második eset}

Egy 76 éves nőbeteg kereste fel ambulanciánkat bal oldali halláscsökkenés panaszával, amelyhez bal oldali fülzúgás és autophonia társult. Az elvégzett tisztahangküszöb-audiometriai vizsgálattal bal oldali, mély frekvenciákat érintő, döntően vezetéses halláscsökkenés ábrázolódott, amelyhez kétoldali presbyacusis társult (9. ábra). STR (10. ábra) és VEMP (11. ábra) egyaránt kiváltható volt, így a hallócsontláncolatot érintő kórfolyamat lehetőségét kizárhattuk. Sziklacsont-HRCT-vizsgálattal harmadikablak-szindróma jelenlétét igazoltuk, a csontos dehiscentia a bal felső ívjáraton helyezkedett el (12. ábra). A beteg a javasolt mútéti ellátást elfogadta, amelynek során idegsebész kolléga bevonásával közép-
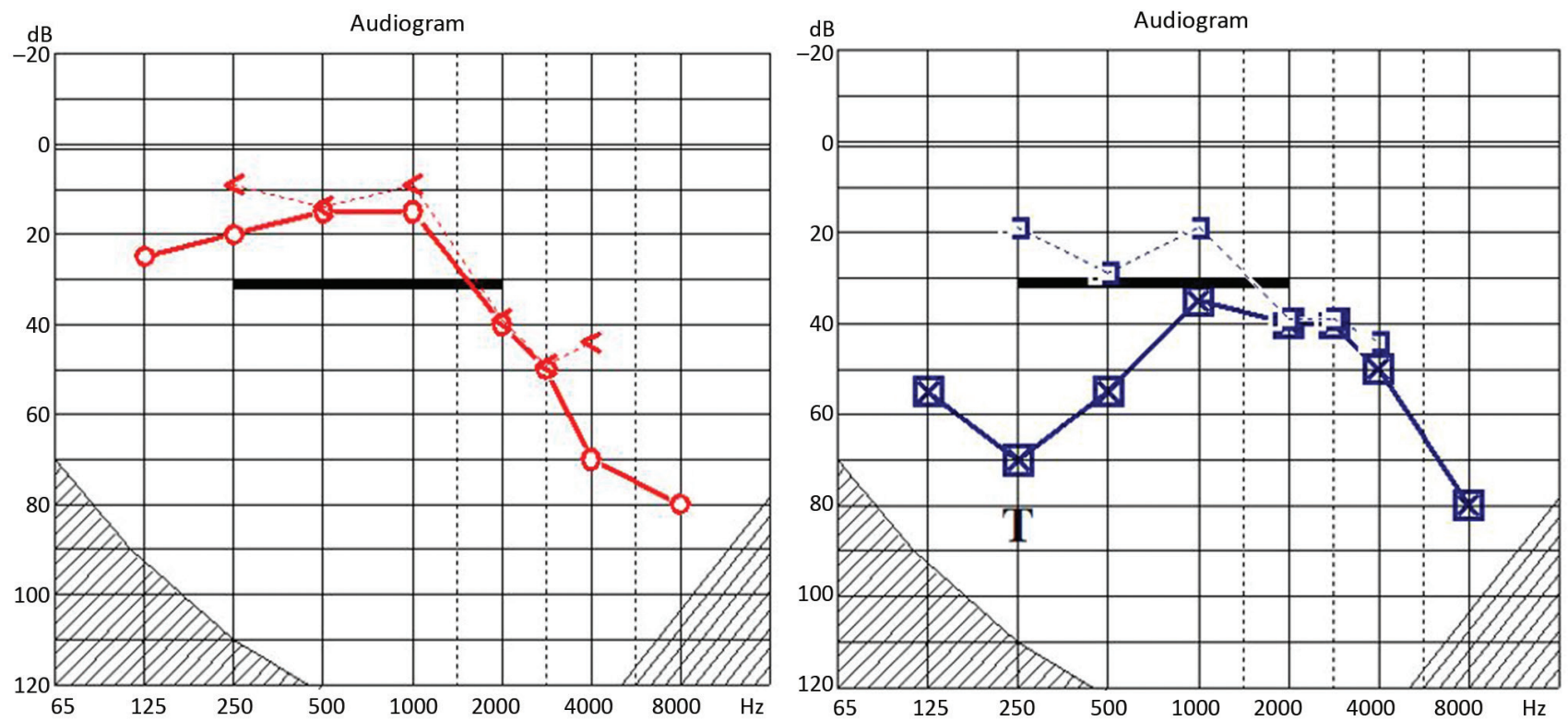

9. ábra $\quad$ Egy 76 éves nóbeteg tisztahangküszöb-audiometriai lelete. Jobb oldalon 1000 Hz-ig közel ép hallás, majd magasabb frekvenciákon nagyfokúvá váló sensorineuralis halláscsökkenés látható. Bal oldalon mély frekvenciákon közepes, majd nagyfokú, $500 \mathrm{~Hz}$-en ismételten közepes fokú, kevert típusú halláscsökkenés, majd 1 kHz-től kis-közepes fokú, végül nagyfokú, döntően sensorineuralis halláscsökkenés képe látható; tinnitus 250 Hz-en mérhető 
sőscala-feltárásból (op.: prof. Gerlinger I. és prof. Dóczi T.) az ívjárati dehiscentiát az occlusio és a fedés módszerének kombinálásával láttuk el (13. ábra). A mútétet követően $250 \mathrm{~Hz}$-en a küszöb $30 \mathrm{~dB}$-t javult, a csont-légrés 15 dB-re csökkent, míg az 500-3000 Hz frekvenciák átlagában a csont-lég-rés $10 \mathrm{~dB}$-ről 6,25 dB-re csökkent; a beteg fülzúgása megszúnt (14. ábra).

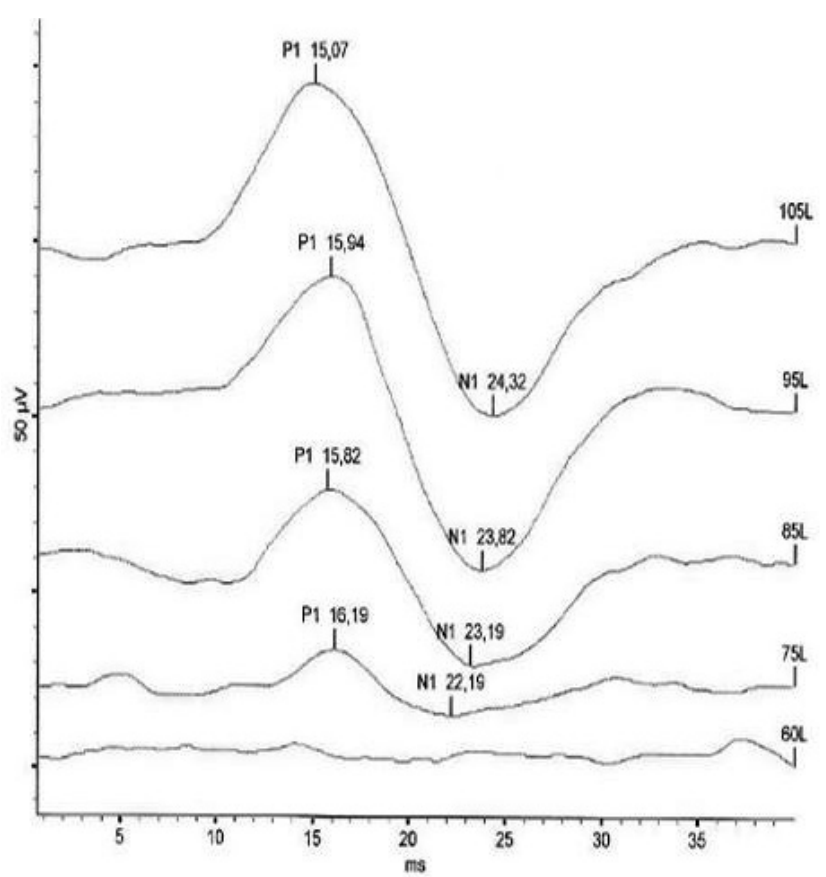

11. ábra

Egy 76 éves nóbeteg VEMP-lelete. Látható a típusos $\mathrm{P}_{1} \mathrm{~N}_{1}$-válasz, amely $75 \mathrm{~dB}$-es hanggal is kiváltható

VEMP = vestibularisan kiváltott miogén izomválasz

\section{Következtetés}

Az ép dobhártya mellett észlelt vezetéses halláscsökkenés etiológiájának tisztázása körültekintést igénylő feladat, amely a klinikust kihívás elé állítja. Az anamnesztikus adatok, a sokszor jellegzetes panaszok gondos kikérdezése mellett kulcsfontosságú szerepe van a teljes körú audiológiai kivizsgálásnak. A tisztahangküszöb-audiometria során az audiogramon harmadikablak-szindróma esetén jellemzően vezetéses vagy kevert típusú halláscsökkenés képét látjuk. A kimutatott csont-lég-rés differenciáldiagnosztikájában a reflexen alapuló objektív audiológiai teszteknek döntő szerepük van, mert a hallócsontláncolatot érintő kórképektől a harmadikablak-szindrómára gyanús eseteket jól differenciálja. Amennyiben normális akusztikus reflexek és kiváltható VEMP mellett regisztráljuk a halláscsökkenést, az megerősíti a gyanút a harmadikablak-szindróma jelenlétére. A belső fül csontos tokjának strukturális eltéréseit jelenleg a sziklacsont HRCT-vizsgálatával tudjuk a legpontosabban kimutatni, ennek elvégzése elengedhetetlen a diagnózis felállításához. Ahogyan azt a második esetünk mutatja, a teljes körű audiológiai kivizsgálás, valamint a megfelelő képalkotó vizsgálatok elvégzése feltétlenül szükséges, mert ezek eredményének együttes értékelésével elkerülhetjük a diagnosztikus tévedéseket, illetve a feleslegesen elvégzett exploratív tympanotomiát [16]. Az irodalomban a leggyakrabban a felső ívjárati dehiscentiával találkozunk [5-7, 13]. A felső ívjárati dehiscentia mútéti megoldására számos eljárást dolgoztak ki [29]. Második esetünknél a felső ívjárati dehiscentiát középsőscala-feltárásból láttuk el idegsebész kolléga bevonásával, mert ilyenkor direkt rálátást nyerünk a defektusra, elkerülhetjük a csontos la-

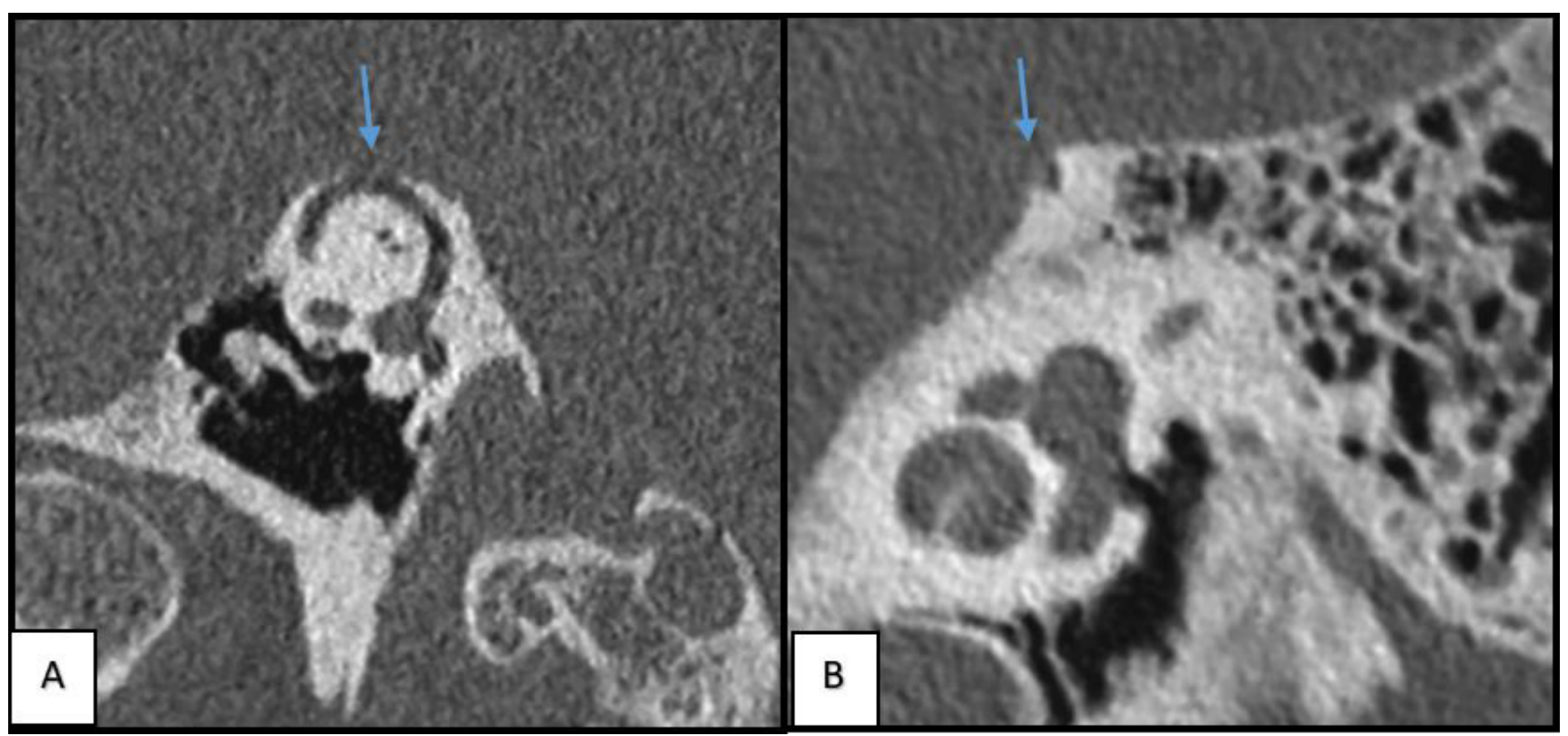

12. ábra Egy 76 éves nőbeteg sziklacsont-HRCT-felvételei (A: koronális, B: sagittalis síkú felvétel). Nyíllal jelöltük a felső ívjárati dehiscentiát HRCT = nagy felbontású komputertomográfia 


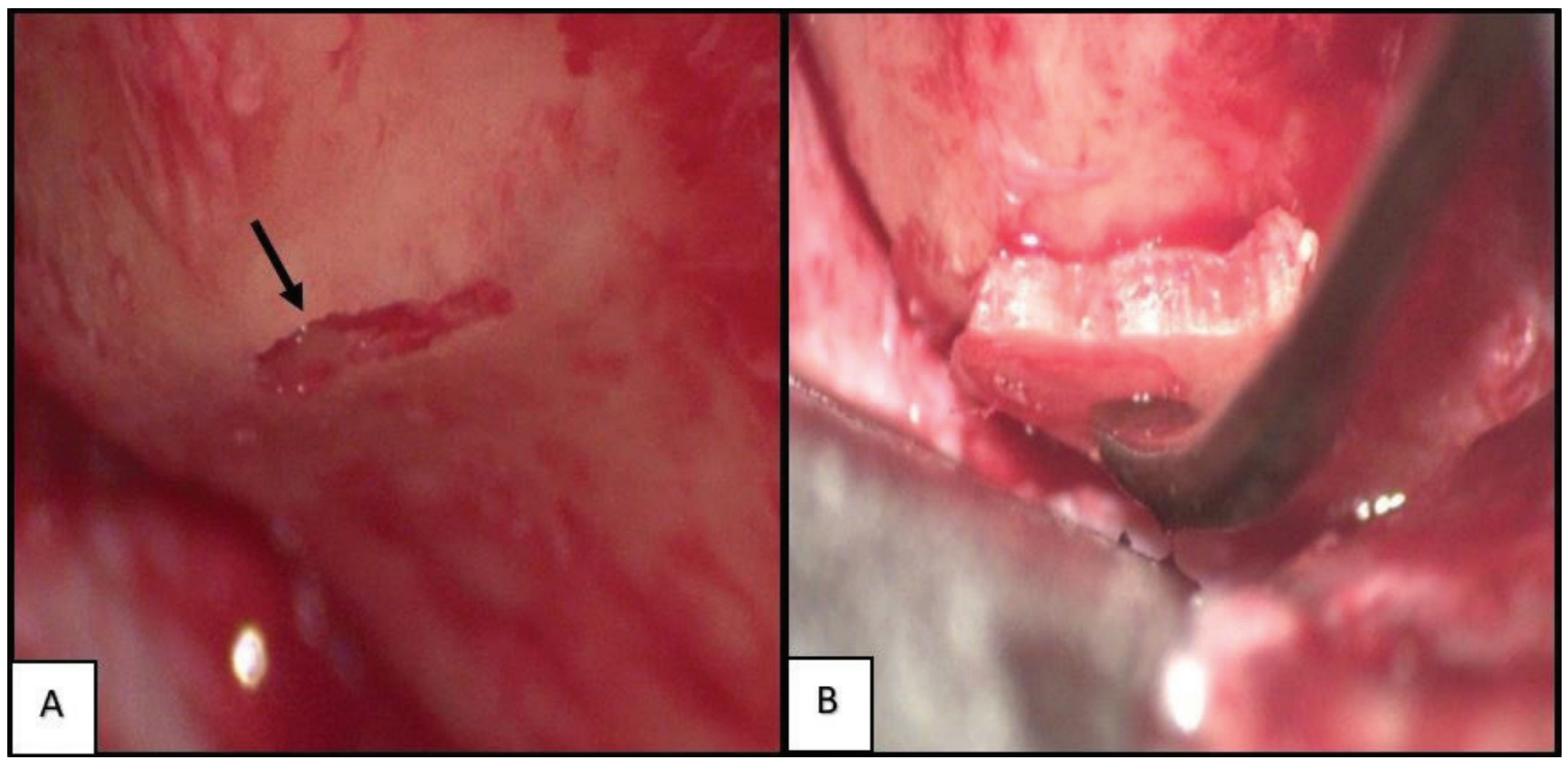

13. ábra $\mid$ Mútéti felvételek. A) Bal oldali középsőscala-feltárást követően a temporalis lebeny felemelésével az eminentia arcuaton látható a felső ivjárati dehiscentia (fekete nyíl). B) A nagyobb nagyítással készült felvételen látható a defektus ellátása, amelynek során az ívjárat occlusióját és fedését végeztük el
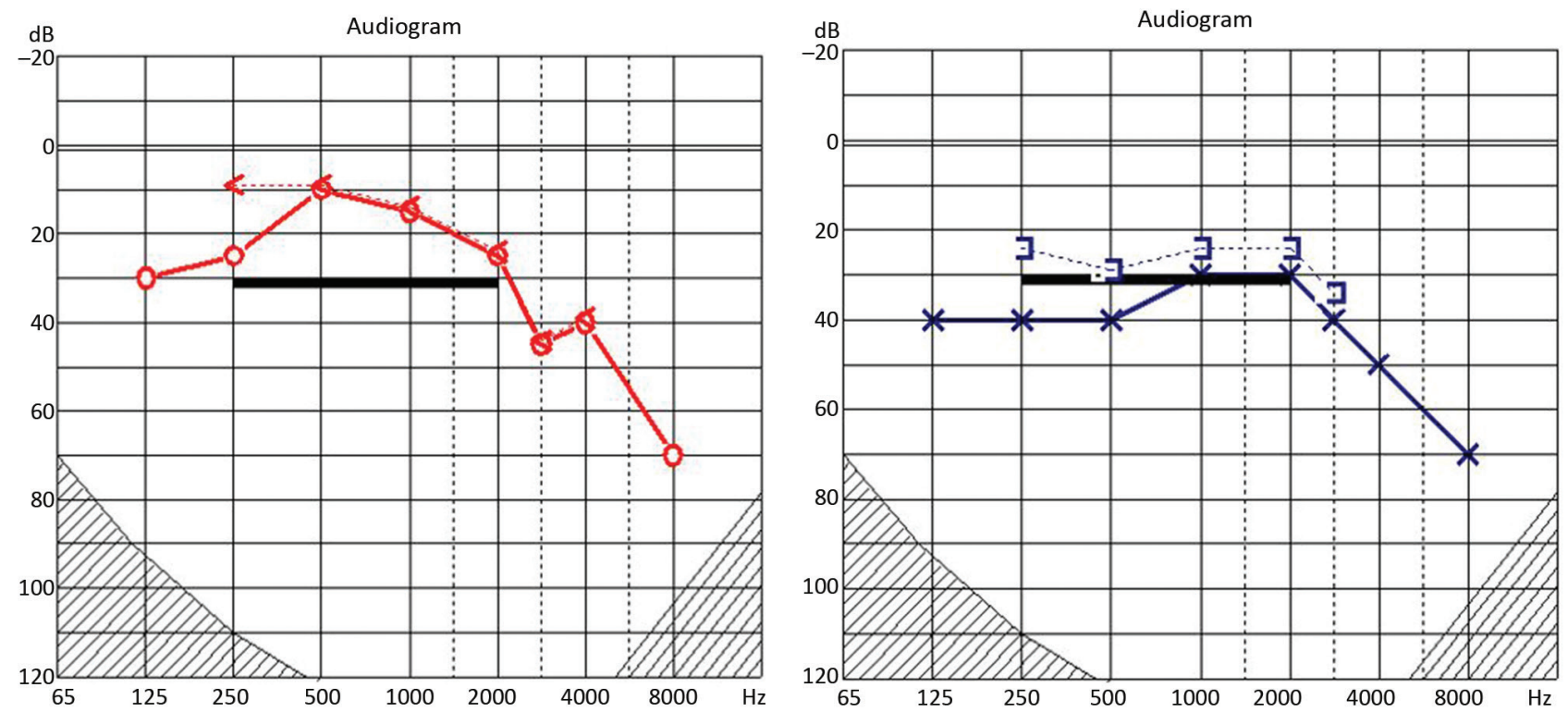

14. ábra $\mid$ Egy 76 éves nőbeteg tisztahangküszöb-audiometriai lelete. Az operációt követően mély frekvenciákon a beteg hallása jelentősen javult, a csont-lég-rés bal oldalon az 500-3000 Hz frekvenciák átlagán 10 dB-ról 6,25 dB-re csökkent; tinnitus nem mérhető

byrinthus bizonyos részeinek elfúrását, valamint a koponyabázis szélesebb feltárását [27]. A defektus ellátása során az occlusiós technikát fedéssel kombinálva alkalmaztuk, mivel irodalmi adatok alapján ez a módszer biztosítja a legjobb tartós eredményt $[26,32,31]$.

Amennyiben a kivizsgálás során a beteg panaszaival az audiogram mintázata, a reflexen alapuló vizsgálatok eredménye, valamint a HRCT-vizsgálat lelete koherens képet mutat, úgy felállítható a harmadikablak-szindróma diagnózisa. A páciens számára mútéti kezelés javasolható, ha a csontos defektus zárása technikailag kivitelez- hető. A legalkalmasabb mútéti technika kiválasztásában a laesio elhelyezkedésének, méretének, valamint az operatőr preferenciájának van szerepe.

A bemutatott esetek kapcsán hangsúlyozandó, hogy a harmadikablak-szindróma felismerése komplex, körültekintő vizsgálatot igényel, és előfordulnak diagnosztikus tévedések. Fontos, hogy amennyiben a kórkép gyanúja felmerül, az érintett beteget erre szakosodott centrumba kell irányítani, ahol lehetôség nyílik a teljes körü kivizsgálásra, és a megfelelő fülsebészeti ellátás is rendelkezésre áll. 
Anyagi támogatás: A közlemény megírása anyagi támogatásban nem részesült.

Szerzői munkamegosztás: K. P.: Irodalomkutatás, a közlemény megírása. G. I.: Esetgazda, a közlemény tartalmi és nyelvhelyességi ellenőrzése. R. P., B. P.: A közlemény tartalmi és nyelvhelyességi ellenőrzése. V. I., K. M.: Ábraszerkesztés. F. A.: Irodalomkutatás. A cikk végleges változatát valamennyi szerző elolvasta és jóváhagyta.

Érdekeltségek: A szerzőknek nincsenek érdekeltségeik.

\section{Irodalom}

[1] Bess FH, Miller GW, Glasscock ME 3rd, et al. Unexplained conductive hearing loss. South Med J. 1980; 73: 335-338.

[2] House JW, Sheehy JL, Antunez JC. Stapedectomy in children. Laryngoscope 1980; 90: 1804-1809.

[3] Al Muhaimeed H, El Sayed Y, Rabah A, et al. Conductive hearing loss: investigation of possible inner ear origin in three cases studies. J Laryngol Otol. 2002; 116: 942-945.

[4] Tonndorf J, Tabor JR. Closure of the cochlear windows: its effect upon air- and bone-conduction. Ann Otol Rhinol Laryngol. 1962; 71: 5-29.

[5] Minor LB, Carey JP, Cremer PD, et al. Dehiscence of bone overlying the superior canal as a cause of apparent conductive hearing loss. Otol Neurotol. 2003; 24: 270-278.

[6] Halmagyi GM, Aw ST, McGarvie LA, et al. Superior semicircular canal dehiscence simulating otosclerosis. J Laryngol Otol. 2003; 117: 553-557.

[7] Mikulec AA, McKenna MJ, Ramsey MJ, et al. Superior semicircular canal dehiscence presenting as conductive hearing loss without vertigo. Otol Neurotol. 2004; 25: 121-129.

[8] Stenfelt S, Goode RL. Bone-conducted sound: physiological and clinical aspects. Otol Neurotol. 2005; 26: 1245-1261.

[9] Wever EG, Lawrence M. Physiological acoustics. Princeton University Press, Princeton, NJ, 1954.

[10] Voss SE, Rosowski JJ, Peake WT. Is the pressure difference between the oval and round windows the effective acoustic stimulus for the cochlea? J Acoust Soc Am. 1996; 100: 1602-1616.

[11] Minor LB, Solomon D, Zinreich JS, et al. Sound- and/or pressure-induced vertigo due to bone dehiscence of the superior semicircular canal. Arch Otolaryngol Head Neck Surg. 1998; 124: 249-258.

[12] Merchant SN, Nakajima HH, Halpin C, et al. Clinical investigation and mechanism of air-bone gaps in large vestibular aqueduct syndrome. Ann Otol Rhinol Laryngol. 2007; 116: 532-541.

[13] Modugno G, Brandolini C, Savastio G, et al. Superior semicircular canal dehiscence: a series of 13 cases. ORL J Otorhinolaryngol Relat Spec. 2005; 67: 180-184.

[14] Mikulec AA, Poe DS. Operative management of a posterior semicircular canal dehiscence. Laryngoscope 2006; 116: 375-378.

[15] Monsell EM. The mechanism of hearing loss in Paget's disease of bone. Laryngoscope 2004; 114: 598-606.

[16] Bance $M$. When is a conductive hearing loss not a conductive hearing loss? Causes of a mismatch in air-bone threshold measurements or a "pseudoconductive" hearing loss. J Otolaryngol. 2004; 33: 135-138

[17] Brantberg K, Bagger-Sjöbäck D, Mathiesen T, et al. Posterior canal dehiscence syndrome caused by an apex cholesteatoma. Otol Neurotol. 2006; 27: 531-534.
[18] Juers AL. Observations on bone conduction in fenestration cas es; physiological considerations. Ann Otol Rhinol Laryngol. 1948; 57: 28-40.

[19] Snik AF, Hombergen GC, Mylanus EA, et al. Air-bone gap in patients with X-linked stapes gusher syndrome. Am J Otol. 1995; 16: 241-246.

[20] Nance WE, Setleff R, McLeod A, et al. X-linked mixed deafness with congenital fixation of the stapedial footplate and perilymphatic gusher. Birth Defects Orig Artic Ser. 1971; 7: 64-69.

[21] Glasscock ME 3rd. The stapes gusher. Arch Otolaryngol. 1973; 98: 82-91.

[22] Phelps PD, Reardon W, Pembrey M, et al. X-linked deafness, stapes gushers and a distinctive defect of the inner ear. Neuroradiology 1991; 33: 326-330.

[23] Cremers CW, Snik AF, Huygen PL, et al. X-linked mixed deafness syndrome with congenital fixation of the stapedial footplate and perilymphatic gusher (DFN3). Adv Otorhinolaryngol. 2002; 61: 161-167.

[24] Talbot JM, Wilson DF. Computed tomographic diagnosis of $\mathrm{X}$-linked congenital mixed deafness, fixation of the stapedial footplate, and perilymphatic gusher. Am J Otol. 1994; 15: 177182.

[25] Kim HH, Wilson DF. A third mobile window at the cochlear apex. Otolaryngol Head Neck Surg. 2006; 135: 965-966.

[26] Vlastarakos PV, Proikas K, Tavoulari E, et al. Efficacy assessment and complications of surgical management for superior semicircular canal dehiscence: a meta-analysis of published interventional studies. Eur Arch Otorhinolaryngol. 2009; 266: 177-186.

[27] Chien WW, Carey JP, Minor LB. Canal dehiscence. Curr Opin Neurol. 2011; 24: 25-31.

[28] Rodgers B, Lin J, Staecker H. Transmastoid resurfacing versus middle fossa plugging for repair of superior canal dehiscence: comparison of techniques from a retrospective cohort. World J Otorhinolaryngol Head Neck Surg. 2016; 2: 161-167.

[29] Ziylan F, Kinaci A, Beynon AJ, et al. A comparison of surgical treatments for superior semicircular canal dehiscence: a systematic review. Otol Neurotol. 2017; 38: 1-10.

[30] Teixido M, Seymour PE, Kung B, et al. Transmastoid middle fossa craniotomy repair of superior semicircular canal dehiscence using a soft tissue graft. Otol Neurotol. 2011; 32: 877-881.

[31] Fiorino F, Barbieri F, Pizzini FB, et al. A dehiscent superior semicircular canal may be plugged and resurfaced via the transmastoid route. Otol Neurotol. 2010; 31: 136-139.

[32] Ward BK, Agrawal Y, Nguyen E, et al. Hearing outcomes after surgical plugging of the superior semicircular canal by a middle cranial fossa approach. Otol Neurotol. 2012; 33: 1386-1391.

[33] Goddard JC, Wilkinson EP. Outcomes following semicircular canal plugging. Otolaryngol Head Neck Surg. 2014; 151: 478483.

[34] Shaia WT, Diaz RC. Evolution in surgical management of superior canal dehiscence syndrome. Curr Opin Otolaryngol Head Neck Surg. 2013; 21: 497-502.

[35] Peng A, Shaia WT. Endoscopic repair of superior canal dehis cence. Presented at the Virginia Society of Otolaryngology Annual Meeting, Charlottesville, VA, May 1-2, 2010.

[36] Silverstein H, Kartush JM, Parnes LS, et al. Round window reinforcement for superior semicircular canal dehiscence: a retrospective multi-center case series. Am J Otolaryngol. 2014; 35: $286-293$.

(Kalinics Péter dr.,

Szekszárd, Béri Balogh Ádám u. 5-7., 7100 e-mail: kalinics.peter@gmail.com)

A cikk a Creative Commons Attribution 4.0 International License (https://creativecommons.org/licenses/by/4.0/) feltételei szerint publikált Open Access közlemény, melynek szellemében a cikk bármilyen médiumban szabadon felhasználható, megosztható és újraközölhető, feltéve, hogy az eredeti szerző és a közlés helye, illetve a CC License linkje és az esetlegesen végrehajtott módosítások feltüntetésre kerülnek. (SID_1) 